\title{
Risk perception, a key component of systemic vulnerability of the coastal zones to erosion-submersion. A Case study on the French Mediterranean coast
}

Catherine Meur-Férec, Géomer, UMR 6554 CNRS LETG, Institut Universitaire Européen de la Mer, Université de Bretagne Occidentale, Université Européenne de Bretagne, Plouzané, France, meurferec@univ-brest.fr

Hervé Flanquart, Université Lille Nord de France, F-59000 Lille TVES (EA 4477), F 59170 Dunkerque, France, hflanquart@yahoo.fr

Anne-Peggy Hellequin, Université Lille Nord de France, F-59000 Lille TVES (EA 4477), F 59170 Dunkerque, France, aph@univ-littoral.fr

Bénédicte Rulleau, REEDS, EA 4456, Université de Versailles Saint Quentin en Yvelines, Guyancourt, France, benedicte.rulleau@reeds.uvsq.fr

\begin{abstract}
This research is based on a view of vulnerability comprised of four main components: hazards (marine-meteorological factors and climate change, geomorphologic process), assets at stake (identification and valuation, commercial and non commercial goods, damage valuation), management (public policies of prevention and reparation), and perception of risk. Risks perception has a major position in systemic vulnerability evaluations because it gives precious indications on the variability of the points of view of the stakeholders, the degree of conscientiousness and sensibility of the exposed inhabitants, their attachment to their territory, their reactions to the hazards, etc. So it provides indications on their adaptation capacity. The results of a large survey conducted in 2009 of over more than 560 inhabitants and shopkeepers of a low and very urbanised stretch of the French Mediterranean coast (Palavas zone, Hérault) are analysed.
\end{abstract}

Keywords: coastal risks, marine inundation, systemic vulnerability, risk perception, sociological survey, France

\section{Introduction: coastal systemic vulnerability, a fundamental concept in which per- ception is an essential component}

Our coasts are in constant motion because of specific dynamic forces due to natural processes that confer intrinsic movement, sometimes increased by human actions. In addition, the acceleration of the sea level rise, in a context of global change and post glacial period sediment shortage, lets us predict that coastal movement will enhance in the future. This specific coastal dynamic becomes a source of risks when in resonance with social issues. On the one hand, the coastline is retreating inland; on the other hand, settlements are becoming more concentrated near the sea. Both natural evolution and human occupation have resulted in a predictable "telescoping" over the last century. These converging dynamics are at the source of the emergence and proliferation of the risks associated with coastline movement. They tend to spread to the more urbanised coastlines in the world (Meur-Férec and Morel, 2004). In this context and considering sustainable development objectives, systemic coastal vulnerability is a concept that might help to understand the processes and to make choices for coastal management.

Systemic vulnerability emerges as a key concept in developing strategies for long term coastal management. This notion implies a multidimensional concept, and therefore an inter- 
disciplinary approach to risk, allowing estimating "the fragility of a system as a whole" (D'Ercole and Pigeon, 1999). Vulnerability therefore characterises a society (or individual) subject to a risk according to situational factors (hazard) but also structural factors determined by the socio-economic, cultural, functional and institutional context of a place and time.

Systemic vulnerability would have, in our view, four major components: hazards (natural phenomena sometimes influenced by human actions, such as cliff erosion, flooding of dunes, etc.); stakes involved (people and property exposed to hazards); management (public policies of prevention and crisis management, defence equipment against the sea); and perception (knowledge and awareness of risk, attachment to the territory, adaptation capacity...) (Meur-Férec et al. 2003 and 2004; Meur-Férec 2006).

The in-depth study of these four components of vulnerability aims to clarify strategic choices for the long-term management of the coasts. To which defence against the sea? To which strategic retreat? The answers of course are numerous and the choices are not up to scientists to make. Nevertheless is useful for decision makers to be informed by studies showing the contribution to the vulnerability of the different parameters in their decisions. The search for pertinent and operational indicators to establish a diagnosis of vulnerability is indeed the first step toward a systemic approach to sustainable management of these coastal risks.

In addition, this comprehensive approach to vulnerability allows us considering the importance of some of these components as relative. Although hazard is consubstantial with risk, it is not the only source of vulnerability and its study, isolated from other components, is not enough to constitute a study on risk. On the other hand, the political choices of localisation issues (e.g. new buildings) and risk management (establishing risk prevention plans, allocating building permits, etc), play an essential role in producing coastal areas at risk and are a key lever for reducing vulnerability. Finally, the dimension that we develop in this article, risk perception by the inhabitants of a coastal territory, is becoming more essential in understanding the social dynamics in a territory. Although long neglected (Peretti-Watel, 2003), studying this component of vulnerability is essential for setting a direction, because it informs on the adaptation capacity of the society and helps us to move toward "good governance" of risks ${ }^{1}$.

The second part of this article is devoted to the issue of risk perception. The third part presents the survey site and the methodology used. The results are presented in part four. Finally, we present our conclusions and perspectives for further research.

\section{Risk perception}

Perceiving a risk is making an estimate on the likelihood of an adverse event happening and the damage that this event may cause. The expert makes estimates based on scientific knowledge that includes the probabilities of occurrence of the event, its probable intensity and the economic valuation of property destroyed.

The lay person often has a more local knowledge, which sometimes allows him to better appreciate certain aspects of the risk than the expert (Wynne, 1996). But this knowledge is often too fragmented and too tied to emotions and private interests for the perception not to be, in many respects, faulty (Horlick-Jones, 1998). There are abundant studies, psychological, sociological and anthropological, that detail all the causes of inaccuracy and variability of risk

$1 \quad$ In France for example, the storm Xynthia has dramatically demonstrated the vulnerability of these coastal areas, causing 47 deaths on the night of 27 to 28 February 2010, mostly on the coasts of Vendée and Charente Maritime. In addition to the problems of effective warning systems, reliability of the levees and construction permits in submersible areas, the issue of risk perception by the people has acquired a new urgency. 
perception by the lay person. These causes can be of a cultural or social nature, but also simply anthropological. Among the former we may cite the example of poorer people euphemising dangers in a distant future because they have difficulties ensuring their daily lives and therefore find it hard to project far into the future (Douglas and Wildavski, 1984; Heimer, 1988). Regarding the latter, we can cite some biases that are virtually universal (Slovic, Fischhoff and Lichtenstein, 1988) such as ease of representability, which means that we tend to judge as more frequent (more random) events that we imagine more easily (often because the media talks about them more) or that impress us more (Piatella Palmarini, 1995). Participant of both categories is the tendency to fear more what N. Luhman and other German sociologists after him (Hahn et al., 1994) call "gefahr" (danger) - over which the individual has no power, and is completely subjected to -, than the risk - over which we have a minimum of power to reduce, if it cannot be completely avoided. If we use this terminology, sea flooding caused by the global sea level rise related to climate change represents danger for ordinary people, while the flooding of one's car (which can be moved with sufficient warning) is a risk. In our approach to the vulnerability issue, we consider that a territory is even more vulnerable than the perceived risk by its inhabitants is "faulty," in other words, a view far removed from what the experts have tried to objectify (as per current knowledge, which may be subject to controversy and therefore relatively differentiated assessments).

\section{Presentation of the site and survey methodology}

\subsection{The site area}

The sector for the study is situated on the French Mediterranean coast in the Department of Hérault. It is a low sandy coast with a lido and lagoon morphology. The area includes 3 predominantly touristic and residential communes: Mauguio, Palavas-les-Flots and Pérols

Mauguio has 15,514 inhabitants, Palavas-les-Flots 5974 and Pérols 8545 (INSEE, 2006). These municipalities are characterized by both strong population growth between the last two censuses of 1999 and 2006, and an aging population.

We chose to retain only the census tracts of the French Institute of Statistics and Economic Studies (INSEE) that are within two kilometres of the coastline. We postulate that the inhabitants of these census tracts, in close contact with the sea, are potentially more affected by the risk of marine inundation.

\subsection{Methodology}

The target population includes all individuals who own or use goods or services, commercial or not, potentially exposed to the hazard of marine inundation, i.e. residents (primary and secondary) and shopkeepers.

For residents, the topics addressed were (1) housing (type of habitat and degree of resident mobility), (2) local attractive features and place attachment, (3) uses of the beach and lagoons, (4) knowledge of the risk of marine inundation and feeling of exposure, (5) ability to mobilize and (6) social and economic variables. The questionnaire consisted of 158 questions, most of them closed (multiple-choice, scaled, etc.), a few open.

The sampling method was based on the population concerned. For the residents, the approach was to use quotas, calculated on the allocation between principal and secondary residences. Since the target population of shopkeepers was relatively small, the sample was as exhaustive as possible. 
The interviews were conducted face-to-face on site (at the homes of the residents and at work for the shopkeepers) in two phases, the first in April 2009, during the spring holidays, and the second in July 2009 during the summer holidays. On the whole, 563 people were interviewed: 318 principal residents, 163 secondary residents and 81 shopkeepers.

\section{Results}

\subsection{Fear and confidence}

\subsubsection{Few environmental risks present}

When respondents were asked to choose from a wide range of risks of all types, we found that their fears are greater toward non-environmental risk. The first choice was fear of serious illness (34\% cited at least once) followed by car accidents (19.5\%). These are two personal risks whose existence is reminded daily by the media and conversations with peers, and thus appear to be very real risks from which one can never feel completely safe. If illness is more feared than car accidents, it is probably because it's what N. Luhman calls "danger", for which we have little or no control (see above). Three environmental risks are cited next, but far from the first, since water pollution is selected by only $9 \%$ of the respondents, flooding by $7.5 \%$ and air pollution by $6 \%$. Therefore, fear of flooding is rated fourth for this population settled on a low coastal area.

It already appears from these first results that the risk of flooding / submersion is not something that preoccupies the inhabitants of the survey area, making them forget their other concerns and worries. It is true that unlike serious illnesses or car accidents - even air or water pollution - a flood is only rarely associated, in the minds of people, with lethal danger ${ }^{2}$.

\subsubsection{Pollution is generally more feared than flooding by rising sea level}

When we concentrated on environmental risks and asked the respondents to choose the three they consider to be the most important for their coastal area, "sea and lagoon pollution" was most often selected (55\% cumulative frequency), followed by water or air pollution (50\%); The modalities related to an increase of sea level (45.5\%) and flooding by the sea or lagoons (43\%) came after.

This relative indifference to the danger of sea flooding is not without consequence on home planning within the territory.

\subsubsection{Personal projections geographically very stable and confident in the future}

To the question "Where do you think you'll be living in twenty years?" ${ }^{3} 45 \%$ of the principal residents responded "in the same home". If we add those who responded "in the same commune but a different home" and "in another coastal commune of the Montpellier area" or "in the region", $70 \%$ of principal residents want to stay in an identical coastal environment or close by. As for secondary residents, to the question "do you think you will still have this residence in 20 years?' $72 \%$ answered yes.

Moreover, when we asked principal and secondary residents to estimate how the sales value of their home would evolve, $77 \%$ answered that it will "rise" or "remain stable". This result shows once again the trust in the value of real estate, revealing in particular the non consid-

\footnotetext{
$2 \square$ The survey was carried out in 2009, almost one year before the Xynthia storm of 28 February 2010.

3 It should be noted that this question was asked at the beginning of the interview and that the respondents did not know at this point that we were interested in risks of marine inundation.
} 
eration of possible economic consequences of coastal hazards (or the belief in the support of their government ${ }^{4}$ ?).

This confidence in the future of the coast is accompanied by a strong desire to transfer property to heirs: $75 \%$ of primary and secondary residents believe their homes will one day pass on to their children. Again, this prediction of transferring property is much higher among secondary home owners (86\%) than principal home owners (43\%), (Chi-square test significant at a $1 \%$ level).

These figures show a stable projection into the future on the area studied; it is even more pronounced for secondary residents than for principal home owners, probably due to a stronger attachment to the home (which may be the stable point in a career path that often leads to changes of principal residence) and to a weaker knowledge of winter storms. We did not therefore detect signs of significant concern for the future of the coast, at least not enough to counteract the amenities afforded by the coast and to consider moving ones residence, whether it is a primary or secondary one.

\subsubsection{A lot of damage foreseen for sea level rise}

Whereas at the beginning of the questionnaire the subject of marine inundation was not addressed so as not to bias the answers of respondents, it became the subject of more detailed questions later. Thus, when the multiple choice question was asked: "What do you think the effects of the rising sea level in Languedoc-Roussillon will be," without specifying any deadline, $25 \%$ of the responses chosen related to the total or partial disappearance of the beaches. Moreover, if we aggregate the responses "flooding of the land at very low altitude" and "overflowing of lagoons" $30 \%$ of respondents refer to flooding in the areas behind the lido. Finally, when grouping the responses "breaking of the lido" and "flooding [by storm] of the houses on the front line", $28 \%$ of the responses involve damage to the built areas of the lido (Only $1 \%$ answered "don't know" or "other").

To the question: "According to you, what consequences could the sea level rise provoke in your commune over the next 20 years?" $90 \%$ of the residents believe that there will be damage to the built areas and / or roads. $45 \%$ even think that entire neighbourhoods will be uninhabitable.

Concerning the potential long-term damage, when the respondents were asked, in an open question, "How do you imagine the lido and the lagoons in 2100 ?" $42 \%$ imagine the lido radically changed or even submerged by the rising sea level. Overall, $65 \%$ think that the coast will undergo major changes, in a rather negative sense. Only $8 \%$ think that things would remain virtually identical without any specific intervention and $10 \%$ imagine that the environment could be preserved by the actions of man.

The answers to these three questions focusing on the general consequences of sea level rise show that respondents expect very heavy damage, even in the short term (20 years). This rather pessimistic view is likely to be related to the heavy media coverage of global warming being the cause of a sea level rise. However, such results may seem surprising, in

$4 \quad$ In France the «Catnat » system provides compensation to victims if the government believes they were victims of a «natural disaster ». This fund is financed by a compulsory debit (the rate is set by the State) on the insurance contract payments for all citizens. 
light of the personal projections into the future which, as we saw above, are characterised by residential stability and confidence. This discrepancy probably comes from the phenomenon, commonly known in the sociology and psychology of risk as "optimism bias" (Peretti-Watel, 2003), which is to minimise the risks to which one is personally exposed.

\subsection{Which strategies for the future?}

Strategies for future management of the coastline involve several options that are clearly presented today, particularly in the Eurosion report (European Commission, 2004). We must choose, depending on the case, between three main thrusts: (1) hold the line by strengthening defences against the sea in the areas where the collective stakes are the highest, (2) adopt a managed retreat by destroying buildings or facilities where the stakes are limited or where human life is irremediably threatened (3) let the coastal dynamic follow its course where the areas of nature allow it. But, if the theory concerning overall strategy seems clear, population surveys often reveal more complex individual positions.

\subsubsection{Slowly evolving beach protection techniques}

To the question: "To fight against beach erosion you can consider several methods. Which of these methods would you prefer to see put in place?" $41 \%$ of residents are in favour of "hard" works (breakwaters, rip rap, groynes...), 37\% would prefer more flexible methods of beach and foreshore renourishment and $10 \%$ would favour a managed retreat.

This information is particularly valuable because it shows that people are still very attached to traditional methods of beach protection that probably have a significant impact on the population and elected officials by their imposing and therefore reassuring aspect. Yet, these methods are often questioned today, even by the State services that advocated them for a long time (CETMEF guide on management of coastal erosion, 2010). Nonetheless an almost equal rate of respondents would prefer renourishment actions. This may underline an evolution toward the recognition of new techniques having less visual impact and being more in line with coastal dynamics, but that are slow to develop in France. Finally, the rate of $10 \%$ in favour of a managed retreat appears to be relatively high for an option that usually arouses fierce disagreements from the local populations.

\subsubsection{The priority is to protect the community stakes}

In terms of collective protection, the question: "Do you think you should collectively try to protect yourselves against a flooding phenomenon?" was asked for different types of stakes (public facilities, cultural heritage, landscape and nature, economic and tourist activities, a house). The multiple choice answers for each stake were "yes, whatever the cost is," "yes, if the cost is reasonable," "no, it is too expensive," " no, it is inevitable in the long term."

The first point that emerges from the results is the strong desire for collective protection of the stakes involved. Overall, for the stakes as a whole, 33\% of the respondents believe that they must be protected collectively "whatever the cost" and $40 \%$ "if the cost is reasonable." Only $14 \%$ think they should not be protected collectively because the flooding is "inevitable" and $10 \%$ because it is "too expensive".

If we analyse the responses in more detail, it appears that a certain hierarchy of the stakes involved emerges. The desire for collective protection is stronger for collective goods such as public service amenities (84\%), (national) heritage buildings (79\%) and natural sites $(76.5 \%)$. The responses are also very positive, but more correlated to the cost, for the economic activities (73\%). Finally, the collective protection of individual property, such as a house, also 
gets a majority of "yes" (52.5\%), but it depends more heavily on cost and above all, is the only issue for which a large proportion of respondents answered "no" (42\%). The defence of an individual home by the community seems to raise questions. Yet it is the system that has prevailed in France until now by the "Catastrophe Natural" funds, an insurance based on the principle of solidarity (everyone pays the same amount, whether exposed to risk or not).

\subsubsection{A very small investment in the protection of personal property}

In terms of private individual protection, to the questions "Have you personally built defences to protect yourself" and "Have you made special arrangements in anticipation of being flooded by the sea," 93\% (88\% residents and 100\% shopkeepers) answered "no". A very small proportion of the surveyed population has therefore taken measures. $5 \%$ of the residents have worked on elevating the lower parts of their homes, $7 \%$ have made special arrangements such as constructing walls, purchasing planks, installing drainage systems, water proofing doors etc.

The risk of flooding was very rarely substantiated by physical interventions on personal property, possibly because the need for it is not felt by the residents. Indeed, $90 \%$ of the residents and shopkeepers who were asked "Have you already been flooded by the sea in this last 10 years?" said it was not the case.

When the residents were asked: "Suppose there is a genuine need to protect yourself against flooding by the sea, would you be willing to pay to build your own defences to protect your home within the next 20 years?" Responses were divided: 57\% answered "no" and 41\% answered "yes".

Among the negative answers, the reasons put forward were firstly the low exposure to risk: $21 \%$ chose the answer "I live upstairs / at a sufficient distance from the sea and don't feel really concerned by this risk," to which we might add the $12 \%$ who responded "I am not the owner, this would be for him to pay." $19 \%$ feel that it is a lost cause: "The damage is inevitable anyway." $17 \%$ believe that these expenses should be borne collectively, "The State or regional governments should pay" or "The municipality should pay."

This shows that though respondents are in favour of collective protections for public facilities, the issue of protecting individual property arises, both in collective terms and in individual initiatives.

\section{Conclusions and perspectives: toward indicators of adaptation?}

The results of this type of survey on the perception of risk can be particularly useful in establishing a long-term management of coastal settlements. Not taking into account this component of the vulnerability could delay or even undermine the implementation of public policies for prevention (information, Land Use Plan, managed retreat, etc.), crisis management and damage repairs (cost sharing). Here again, the example of the poor management of the French coastlines recently affected by the Xynthia storm surge, is meaningful.

Beyond the analysis of these results, we would like to go further to develop indicators that provide information about the responsiveness / adaptation of populations concerned. The goal is to understand and explain the behaviours and possible adaptations by the residents of the survey area faced with the risk of marine inundation, but also and above all, to help forge a decision making tool which can be transposed in other coastal areas. 
Based on three series of questions from our survey, we are working to create three indicators: (1) an indicator of greater or lesser sensibility to this risk ("spontaneous" reference to risk, situations compared to other risks, etc.). (2) an indicator of residential mobility or lack thereof (voluntary or involuntary), (3) an indicator of attachment to the place. These dimensions will be crucial in addressing the issue of a population's adaptation capacity.

\section{Acknowledgements}

This study was conducted in the framework of the project: « Marine Inundation hazard exposure modelling and Social, Economic and Environmental Vulnerability Assessment in regard to global changes » (MISEEVA) financed by the French National Research Agency (Agence Nationale de la Recherche). This program as a whole is presented in another paper of the conference proceedings. The authors would like to thank all the members of the project for their comments and suggestions, as well as the people who participated in the data collection effort. $^{5}$.

\section{References}

European Commission, 2004. Living with coastal erosion in Europe: Sediment and Space for Sustainability. Official UE publication office, Luxembourg, $40 \mathrm{p}$

D'Ercole, R., Pigeon, P. (1999) L'expertise internationale des risques dits naturels : intérêt géographique, Annales de géographie, 608, 339-357.

Douglas M. and Wildavski A., Risk and Culture, an Essay on the Selection of Technological and Environmental Dangers, University of California Press, 1984

Hahn A. Eirmbter W.H., Jacob R., 1994. Sida: savoir ordinaire et insécurité, Actes de la Recherche en Sciences Sociales, 104, 81-89.

Heimer C. A., 1988. Social structure, psychology, and the estimation of risk. Annual Review of Sociology, 14, 491-519.

Horlick-Jones T., 1998. Meaning and contextualisation in risk assessment. Reliability engineering and system safety 59, 79-89.

Kahnemann D., Slovic P. Tversky A., 1988. Judgement under incertainty, Cambridge Univ.Press.

Meur-Ferec C., Deboudt P., Deldrève V., Flanquart H., Hellequin A.-P., Herbert V. et Morel V., 2003-2004. La vulnérabilité des territoires côtiers: évaluation, enjeux et politiques publiques, Programme National Environnement Côtier (PNEC).

Meur-Férec C., Morel V., 2004. L'érosion sur la frange côtière : un exemple de gestion des risques. Nature Science et Société 12, 263-273.

Meur-Ferec C., 2008. De la dynamique naturelle à la gestion intégrée de l'espace littoral : un itinéraire de géographe. Edilivre, Collection universitaire, Paris, 250 p.

Ministère de l'Ecologie, de l'Energie, du Développement durable et de la mer, 2010. La gestion du trait de côte. Editions Quae, Paris, 290 p.

Peretti-Watel P., 2003. La sociologie du risque, Paris, Armand Collin.

Piattelli Palmarini M., 1995. La réforme du jugement ou comment ne plus se tromper, Paris, O. Jacob

Wynne B., 1996. Controverses, indétermination et contrôle social de la technologie. Leçons du nucléaire et de quelques autres cas au Royaume-Uni. Le principe de précaution dans la conduite des affaires humaines. in O. Godard, Paris, MSH/INRA. 